DOI: https://doi.org/10.26858/est.v5i3.10516

\title{
Improving The Problem Solving Skill Through Metacognitive Strategies Assisted by Student Worksheets
}

\author{
Johan Syahbrudin ${ }^{1}$, Anita Anggraini ${ }^{2}$ \\ ${ }^{1}$ Education Technology, Pamulang University, Indonesia \\ Email: dosen01263@unpam.ac.id \\ ${ }^{2}$ Accounting Education, Pamulang University, Indonesia \\ Email: dosen01262@unpam.ac.id
}

(Received: September-2019; Reviewed: October-2019; Accepted: November-2019;

Avalaibel Online: December 2019; Published: December-2019)

\begin{abstract}
This study aims to investigate the effectiveness of metacognitive learning strategy assisted by student worksheets based on troubleshooting even though only for a short amount of time to develop students' physics problem solving abilities. This research design using quasi-experiment design. The study population was students of class XI MAN Yogyakarta 1 with two sample classes totaling 53 people taken through cluster random sampling techniques. Collecting research data through study documentation, observation, and tests. Analysis of research data using descriptive analysis techniques and quantitative analysis (independent sample t-test). This study shows the results that the application of metacognition learning strategy assisted by student worksheets based on troubleshooting in a relatively short period of time is not effective to produce physics problem solving abilities.
\end{abstract}

Keywords: Metacognitive strategy, Student worksheets, Problem solving ability.

\section{INTRODUCTION}

The ability to solve problems is a fundamental ability needed in life and related to the knowledge possessed by students, where the more experienced they are in solving various problems, the better the ability to solve problems. This shows that it is important to develop this ability, especially through learning physics. Because in learning physics students are accustomed to working on problems, and success in learning is not only determined by how smart they work on physics problems, but also how deep understanding of concepts and skills to solve physics problems. So by learning to practice the skills to solve physics problems, it is hoped that later it can be useful to solve problems that are not only in terms of physics, but also in other areas of daily life.

There are at least five aspects of ability that students must master in solving science problems, in this case physics, namely: the ability of science concepts, the ability to master science skills, the ability to understand science, the ability to be positive towards science and metacognitive abilities (Iskaandar, 2014). And the indicators of problem-solving ability refer to the problem-solving stage that is adapted according to (G.Polya, 1957), which is understanding the problem at hand, making plans to solve it, implementing plans, and reexamining the results of problem solving. So, the ability to solve problems is a very complex intellectual skill, in which to master it requires 
the basic knowledge possessed by someone as a result of the learning process to understand the problem. Basic skills include a number of skills, including: analyzing problems, skills connecting relevant concepts, and skills in planning, choosing and using various suitable alternative solutions, where several stages are closely related to metacognitive abilities or awareness in managing cognitive abilities to solve problem.

Meanwhile, the reality in the field shows that the ability to solve problems, especially in the field of physics by students is still not encouraging, as evidenced by cases of leaked answer keys, cheating on examinations, and so on. This is in line with the findings (Mariam, Rohaeti, \& Sariningsih, 2018), where students still have difficulty in planning the completion model that will be used so that students cannot solve their mathematical problem solving abilities well. The findings (Bernard, Nurmala, Mariam, \& Rustyani, 2018) also show that students have not been able to solve problems completely, nor can they work through the processes and stages to solve problems. The findings (Ulya, 2016) are also in line that there are students who can identify problems but have not been able to write important information in a concise manner, can implement strategies to communicate conclusions but meet obstacles to write solutions in mathematical language, and have not been able to check the results of problem solving and have not been able to arrange the solution in different steps.

Therefore it is necessary to design physics learning that trains students to get used to managing their cognitive abilities and to be good problem solvers, namely metacognitive learning strategies. Why use metacognitive strategies? Because through this strategy, students are trained to be able to organize themselves to achieve learning objectives by choosing effective strategies in solving problems through awareness and self-knowledge abilities. A person's awareness of the process of thinking or thinking about thinking is called metacognition, and this needs to be developed through metacognition learning strategies. In addition, this strategy also shows positive effects, as research results (Zhao, Wardeska, McGuire, \& Cook, 2014) show that metacognitive learning strategies contribute to the improvement of learning throughout the course and curriculum. Metacognitive strategies affect students' mathematical problem solving abilities (Prasetyoningrum \& Mahmudi, 2006).
According to (Zulfikar, 2019) metacognitive approaches affect the ability of mathematical communication and the ability of mathematical representation of students. And the results of the study (Maulana, 2017) show that metacognitive strategies have a significant influence on problem solving abilities. In addition, metacognitive strategies also affect students' metacognition abilities (Sunanto \& Asyiah, 2018).

And because metacognitive abilities can help develop good thinking management skills so they show good academic performance compared to students who have low metacognitive abilities (Panggayuh, 2017). In addition, findings (Valencia-Vallejo, LópezVargas, \& Sanabria-Rodríguez, 2019) show that metacognitive scaffolding promotes significant differences in metacognitive abilities, academic self-efficacy, and learning achievement, even for students with different cognitive learning outcomes. So this metacognitive learning becomes important to do, because in the development of problem solving abilities there needs to be awareness as an effort to manage cognitive abilities in responding to problems that must be solved. Awareness about the ability to think is what is referred to as metacognitive.

Therefore, metacognitive learning strategies can be an alternative to fostering problem-solving abilities, because they play a role in controlling cognitive processes when thinking that can be done through guiding statements such as: "What do you think about when facing a problem that is difficult to solve?" , "What strategies do you use when solving problems?", etc. To achieve learning objectives by choosing effective strategies. As expressed by (Oxford, 1990), there are three metacognitive strategies that can be used and / or developed to achieve learning success, namely focusing learning where there are activities to identify, talk about thinking, keep a thought journal; making learning plans and self-regulation; and do a self evaluation.

The selection of learning strategies needs to pay attention to a variety of learning resources and objectives, because the learning strategy is a plan of learning activities that includes the use of media, methods, and learning resources that are set to achieve learning objectives. And one of the learning media needed to support metacognitive learning strategies in practicing problem solving skills is student worksheets based on problem solving, such as findings 
(Purnamawati, Ertikanto, \& Suyatna, 2017) that Student Worksheets based on proven high-level thinking skills quite influential in growing higher order thinking skills (HOTS). This is in line with the findings (Purwasi \& Fitriyana, 2019), through the use of worksheets based on open problem solving that can improve students' problem solving abilities. So, it is clear that this problem-based worksheet means giving students the opportunity to develop concepts and develop their own skills, so they can help learners' independence in learning and also help guide students in achieving learning goals, besides student worksheets also requires educators to manage learning.

It is clear that the ability to solve problems is a fundamental ability needed in life, and is well developed through learning physics. Meanwhile, students' ability to solve problems, especially in the field of physics is still not encouraging. And given that there are many ways or strategies in developing problem solving skills, for example through the use of metacognitive strategies based on problem solving student worksheets. and because there are differences in the effectiveness of the application of metacognitive strategies, namely short-term effects of metacognitive prompts are effective in learning strategies elicited in the journals, learning success and students' writing motivation (Nückles, Hübner, \& Renkl, 2008), which contradict the findings (Shamsini, 2014) where the application of metacognitive strategies in a relatively short period of time is not very effective for increasing students' understanding of reading comprehension. So this study aims to investigate the effectiveness of metacognitive learning strategy assisted by student worksheets based on troubleshooting even though only for a short amount of time to develop students' physics problem solving abilities.

\section{METHOD}

This research is a quasi experimental design, with a posttest-only design (Creswell, 2012). This design uses two groups, namely the experimental group is treated by applying the metacognition learning strategy assisted by student worksheets based on troubleshooting, and the control group is taught conventionally, then both groups are given a posttest to measure the ability of physics problem solving as the dependent variable.

Sampling of this study using cluster random sampling technique, which is chosen two classes randomly from three classes XI MAN Yogyakarta 1 which are registered in the science specialization in the current school year as its population.

Research data collection techniques include: study documentation, observation, and tests. Study documentation and initial observations are used as needs analysis data, list of learners' names, and relevant studies. Observation of the learning process to determine the suitability of the plan with the implementation of the learning process at each meeting. Test instrument to measure the ability to solve physics problems.

Learning tools, learning process observation sheets, and the instruments of student worksheets based on troubleshooting used in the study were tested for eligibility only by rational internal validity tests, namely the construct and content validity tests by experts or expert judgment, and then revised according to the advice given. The instrument of problem solving ability goes through the stages of the test: internal validity to determine the level of eligibility by experts, and at the same time as a material for revision, then empirical tests are conducted on students who are at the same level, namely class XI to test the feasibility in terms of validity, reliability, difficulty level, and the distinguishing power of the test instrument. From 7 items of problem solving ability tests that were tested and analyzed using the quest program, obtained 5 valid items with a reliability of 0.70 (high reliability). The results of this test can be seen in Table 1 .

There are two data analysis techniques in this study, namely descriptive analysis and quantitative analysis. Descriptive analysis is used to analyze data from observations of learning outcomes based on criteria adapted and developed by (Azwar, 2013), with the score range of each category obtained through calculations as in Table 2. 
Table 1. Empirical Test Results of the Problem Solving Ability Test Instrument

\begin{tabular}{cccc}
\hline No. Items & $\begin{array}{c}\text { Validity } \\
\text { (INFIT MNSQ Value) }\end{array}$ & Difficulty Level & $\begin{array}{c}\text { Distinguishing } \\
\text { Power }\end{array}$ \\
\hline Item 1 & 1.09 (Valid) & 0,65 (Moderate) & 0,56 (Good) \\
Item 2 & 1.15 (Valid) & 0,19 (Difficult) & 0,44 (Good) \\
Item 3 & 1.39 (Invalid) & 0,13 (Difficult) & 0,27 (Cukup) \\
Item 4 & 0.97 (Valid) & 0,26 (Difficult) & 0,58 (Good) \\
Item 5 & 0.82 (Valid) & 0,16 (Difficult) & 0,49 (Good) \\
Item 6 & 0.67 (Invalid) & 0,36 (Moderate) & 0,60 (Good) \\
Item 7 & 0.94 (Valid) & 0,16 (Difficult) & 0,62 (Good) \\
\hline
\end{tabular}

Table 2. Criteria for the Ideal Assessment Category

\begin{tabular}{ccc}
\hline No. & Score Range & Category \\
\hline 1 & $\mathrm{X}>\mathrm{Mi}+1,50 \mathrm{SDi}$ & Very good \\
2 & $\mathrm{Mi}+0,50 \mathrm{SDi}<\mathrm{X} \leq \mathrm{Mi}+1,50 \mathrm{SDi}$ & Well \\
3 & $\mathrm{Mi}-0,50 \mathrm{SDi}<\mathrm{X} \leq \mathrm{Mi}+0,50 \mathrm{SDi}$ & Enough \\
4 & $\mathrm{Mi}-1,50 \mathrm{SDi}<\mathrm{X} \leq \mathrm{Mi}-0,50 \mathrm{SDi}$ & Less \\
5 & $\mathrm{X} \leq \mathrm{Mi}-1,50 \mathrm{SDi}$ & Very less \\
\hline
\end{tabular}

Information:

$\mathrm{X} \quad$ : average total score obtained

$\mathrm{Mi} \quad$ : mean ideal score

SDi : ideal standard deviation

Quantitative analysis using independent sample $\mathrm{T}$ test with prerequisite test in the form of normality test, and the hypothesis testing criteria is $\mathrm{H}_{0}$ is accepted if the probability value (Sig)> 0.05 (Mayers, 2013).

The hypothesized pair of this study are:

$\mathrm{H}_{0}$ : there is no difference in students' physics problem solving abilities through metacognitive learning strategy assisted by student worksheets based on troubleshooting in a short time with conventional learning.

$\mathrm{H}_{\mathrm{a}}$ : there are differences in students' physics problem solving abilities through metacognitive learning strategy assisted by student worksheets based on troubleshooting in a short time with conventional learning.

\section{RESULT AND DISCUSSION}

\section{Result}

Data is collected on research subjects that have been selected by cluster random sampling, and are taught using the specified learning strategies, as well as tests of physics problem solving abilities.

Data from the observations of the suitability of the plan and the implementation of the learning process at each meeting are described and a decision is made based on the criteria determined by adapting the formula developed by (Azwar, 2013). A learning observation sheet with a metacognition learning strategy assisted by student worksheets based on troubleshooting, consisting of 14 statements. The score given is $1-4$, which means the lowest score is 14 and the highest score is 56 , so a Mi score of 35 is obtained, and an SDi score of 7. From the observations, the average score of the implementation of the metacognition learning strategy assisted by student worksheets based on troubleshooting the first meeting was 47 (included in the excellent category), the second meeting was 49.5 (very good), and the first meeting was 51 (very good). So that the implementation of the learning process at each meeting is very in accordance with the plan.

This problem solving ability data is the primary data obtained from the results of the physics problem solving ability test subject of gas kinetic theory. This data is then analyzed to test the research hypothesis. Testing this hypothesis using an independent sample $\mathrm{T}$ test with the normality test as a prerequisite.

The results of the normality test conducted on the problem solving ability score data of each treatment group were processed with the help of 
the SPSS program, the significance value obtained in the Shapiro-Wilk column in the experimental group was 0.130 and in the control group was 0.324 , where the value was greater than 0.05 (Sig.> 0.05) which means that the variance is normally distributed. The results of this normality test can be seen in Table 3 .

Table 3. Normality Test Results Using Shapiro-Wilk

\begin{tabular}{|c|c|c|c|c|}
\hline & \multirow{2}{*}{ Group } & \multicolumn{3}{|c|}{ Shapiro-Wilk } \\
\hline & & Statistic & df & Sig. \\
\hline \multirow{2}{*}{ Problem_solving } & Control & .957 & 27 & .324 \\
\hline & Experiment & .939 & 26 & .130 \\
\hline
\end{tabular}

After the prerequisite tests are fulfilled, continued with the different test using an independent sample T-test to find out whether or not there is a significant difference in the students' physics problem solving abilities through metacognition learning strategy assisted by student worksheets based on troubleshooting with conventional learning. This testing criterion is if the probability value $(\mathrm{Sig})>0.05$, then $\mathrm{H}_{0}$ is accepted (there is no difference in the students' physics problem solving abilities through metacognition learning strategy assisted by student worksheets based on troubleshooting with conventional learning.) And if the probability value $(\mathrm{Sig})<0.05$, then $\mathrm{H}_{0}$ is rejected (there are differences in the students' physics problem solving abilities through the metacognition learning strategy assisted by student worksheets based on troubleshooting with conventional learning). The results of this test can be seen in the following Table 4 .

Table 4. Independent Sample T Test Results

\begin{tabular}{llllllll}
\hline & & \multicolumn{3}{l}{$\begin{array}{l}\text { Levene's Test for Equality } \\
\text { of Variances }\end{array}$} & \multicolumn{2}{l}{ t-test for Equality of Mean } \\
\hline & F & Sig. & t & df & Sig.(2-tailed) \\
\hline $\begin{array}{l}\text { Problem_s } \\
\text { olving }\end{array}$ & $\begin{array}{l}\text { Equal variances } \\
\text { assumed }\end{array}$ & 2.868 & .096 & -1.323 & 51 & .192 \\
\hline
\end{tabular}

\section{Discussion}

This study aims to investigate the effectiveness of metacognitive learning strategy assisted by student worksheets based on troubleshooting even though only for a short amount of time to develop students' physics problem solving abilities. Previous experimental studies have shown that the shortterm effects of metacognitive prompts are effective in learning strategies elicited in the journals, learning success and students' writing motivation (Nückles et al., 2008). This is different from the findings (Shamsini, 2014) which show that the application of metacognitive strategies in a relatively short period of time is not very effective in increasing students' understanding of reading comprehension.

The results of this study indicate that the application of metacognitive learning strategy assisted by student worksheets based on troubleshooting in a short time (only three meetings), is less effective in producing students' physics problem solving abilities. This is different from the findings (Nückles et al., 2008) where the short-term effects of cognitive and metacognitive prompts are effective in learning strategies elicited in the journals, learning success and students writing motivation, and tend to have negative effects if applied for a long time because they are boredom effect. This can happen because the development of physics problem solving abilities is relatively more difficult than the ability to write journals and students' motivation to write learning journals. In addition, because problem solvers usually use many problem solving strategies, such as findings (Saygil1, 2017), where the students whose problemsolving skill was at proficient level used seven 
different strategies, and generally, solved the problems with more than one strategy and the students whose problem-solving skill was at novice level used only four strategies and could not solve four problems. And of course mastering many strategies in solving this problem requires a relatively long time. This is also proven during the learning process, that is when discussing problem solving, some students have difficulty so that it takes longer, and even needs to be continued as homework.

The results of the present study are in line with findings (Shamsini, 2014) where the application of metacognitive in a short time is not very effective in improving students' understanding abilities that produce problemsolving abilities, because after all understanding skills play an important role in solving problem problems. In addition, because of its short application, it can cause students to forget to use their metacognitive abilities when testing, although metacognitive prompting seems to have influenced the performance of students during problem solving test (Aurah, 2018). However, the results show a great similarity, and mutual support.

However, although there was no significant difference in the mean, in fact the average problem solving ability of the experimental group was 64.46, while the control group was 58.22 , which meant that the experimental group was superior to 6.24 compared to the control group. This could be an indication that if the metacognitive learning strategy assisted by student worksheets based on troubleshooting is applied for a relatively long period of time, it might give different results. As a result of research (Nett, Goetz, Hall, \& Frenzel, 2012) that the use of metacognitive strategies can significantly improve student performance over time.

\section{CONCLUSION AND SUGGESTION}

The results of this study indicate that the application of metacognition learning strategy assisted by student worksheets based on troubleshooting in a relatively short period of time is not effective to produce physics problem solving abilities.

The application of metacognitive strategies has been shown to significantly improve student performance over time, and student worksheets based on HOTS have been shown to be quite influential in HOTS growth, including problem solving abilities, so metacognitive learning strategies assisted by student worksheets based on troubleshooting should be done in a relatively long time, because the application in a relatively short time proved ineffective, and vice versa. And another thing that is not less important is that teachers should remind students to use their metacognitive abilities when the test is taking place, because this has also been proven effective.

\section{REFERENCES}

Aurah, C. (2018). The Effectiveness of Metacognitive Prompts on a Genetics Test among High School Students in Kenya. The Eurasia Proceedings of Educational \& Social Sciences (EPESS), 9, 134-142. ISRES.

Azwar, S. (2013). Tes Prestasi. Yogyakarta: Pustaka Pelajar.

Bernard, M., Nurmala, N., Mariam, S., \& Rustyani, N. (2018). Analisis Kemampuan Pemecahan Masalah Matematis Siswa SMP Kelas IX pada Materi Bangun Datar. SJME (Supremum Journal of Mathematics Education), 2(2), 77-83.

Creswell, J. (2012). Educational research: Planning, Conducting, and Evaluating Quantitative and Qualitative Research (4th ed.). Boston: Pearson Education.

G.Polya. (1957). Polya How To Solve It: A New Aspect of Mathematical Method (2nd ed.). New York: Princeton University Press.

Iskandar, S. M. (2014). Pendekatan Keterampilan Metakognitif Dalam Pembelajaran Sains Di Kelas. Erudio Journal of Educational Innovation, 2(2), 13-20. https://doi.org/10.18551/erudio.22.3

Mariam, S., Rohaeti, E. E., \& Sariningsih, R. (2018). Analisis Kemampuan Pemecahan Masalah Matematis Siswa Madrasah Aliyah Pada Materi Pola Bilangan. Journal on Education, 1(2), 156-162.

Maulana, A. (2017). Pengaruh Strategi Metakognitif terhadap Kemampuan Pemecahan Masalah Matematika. JKPM (Jurnal Kajian Pendidikan Matematika), 2(2), 193-200. 
Mayers, A. (2013). Introduction to Statistics and SPSS in Psychology. Bournemouth University: Pearson.

Nett, U. E., Goetz, T., Hall, N. C., \& Frenzel, A. C. (2012). Metacognitive Strategies and Test Performance: An Experience Sampling Analysis of Students' Learning Behavior. Education Research International, 2012, 1-16. https://doi.org/10.1155/2012/958319

Nückles, M., Hübner, S., \& Renkl, A. (2008). Short-term versus long-term effects of cognitive and metacognitive prompts in writing-to-learn. Proceedings of the 8th International Conference for the Learning Sciences, ICLS '08, (2), 124-131. The Netherlands.

Oxford, R. (1990). Language Learning Strategies. New York: Universitas Alabama.

Panggayuh, V. (2017). Pengaruh Kemampuan Metakognitif Terhadap Prestasi Akademik Mahasiswa Pada Mata Kuliah Pemrograman Dasar. JIPI (Jurnal Ilmiah Penelitian Dan Pembelajaran Informatika), 2(1), 20-25. https://doi.org/10.29100/jipi.v2i1.228

Prasetyoningrum, F. D., \& Mahmudi, A. (2006). Pengaruh Strategi Metakognitif Terhadap Kemampuan Pemecahan Masalah Matematis Siswa Kelas Viii Di Smp Negeri 6. Jurnal Pendidikan Matematika, 6(4), 19-27. Retrieved from http://journal.student.uny.ac.id/ojs/index.p hp/pmath/article/download/6971/6696

Purnamawati, D., Ertikanto, C., \& Suyatna, A. (2017). Keefektifan Lembar Kerja Siswa Berbasis Inkuiri untuk Menumbuhkan Keterampilan Berpikir Tingkat Tinggi. Jurnal Ilmiah Pendidikan Fisika Al-Biruni, 6(2), 209-219. https://doi.org/10.24042/jipfalbiruni.v6i2.2 070

Purwasi, L. A., \& Fitriyana, N. (2019). Pengembangan Lembar Kerja Siswa Berbasis Pendekatan Open-Ended Untuk Melatih Kemampuan Pemecahan Masalah Matematis Siswa SMP. Kreano, Jurnal Matematika Kreatif-Inovatif, 10(1), 18-26. https://doi.org/10.15294/kreano.v10i1.168 25
Saygil1, S. (2017). Examining The Problem Solving Skills and The Strategies Used by High School Students in Solving Nonroutine Problems. E-International Journal of Educational Research, 8(2), 91-114. https://doi.org/10.19160/ijer.321075

Shamsini, S. (2014). International Journal of English and Education Metacognitive Strategy Awareness and Its Effect on the Learners , Reading Comprehension Ability: Revisited. International Journal of English and Education, 3(3), 40-59.

Sunanto, L., \& Asyiah, N. (2018). Pengaruh Strategi Metakognitif Terhadap Metakognisi Mahasiswa PGSD. Jurnal THEOREMS (The Original Research of Mathematics), 3(1), 92-98.

Ulya, H. (2016). Profil Kemampuan Pemecahan Masalah Siswa Bermotivasi Belajar Tinggi Berdasarkan Ideal Problem Solving. Jurnal Konseling Gusjigang, 2(1), 90-96. https://doi.org/10.24176/jkg.v2i1.561

Valencia-Vallejo, N., López-Vargas, O., \& Sanabria-Rodríguez, L. (2019). Effect of a metacognitive scaffolding on self-efficacy, metacognition, and achievement in elearning environments. Knowledge Management and E-Learning, 11(1), 1-19. https://doi.org/10.34105/j.kmel.2019.11.00 1

Zhao, N., Wardeska, J., McGuire, S., \& Cook, E. (2014). Metacognition: An Effective Tool to Promote Success in College Science Learning. Journal of College Science Teaching, 43(4), 48-54. https://doi.org/10.2505/4/jcst14_043_04_4 8

Zulfikar, R. N. (2019). Pengaruh Pendekatan Metakognitif Terhadap Kemampuan Representasi Siswa Dalam Pembelajaran Matematika SMK Kesehatan Nusantara Kupang. Jurnal Inovasi Matematika, 1(2), 91-98. https://doi.org/10.35438/inomatika.v1i2.15 3 